\title{
PENCIPTAAN FILM BABAN GALA: REPRESENTASI EKSPRESI PERSONAL SEBAGAI PANGHULU DI MINANGKABAU
}

\author{
Ikrar Fardila \\ Program Pascasarjana Institut Seni Indonesia Padangpanjang, Indonesia \\ Email: ikrarfardila89@gmail.com, Hp: 082284003116
}

\begin{abstract}
Baban Gala isan audio visual workrelatedto personal expressionof a panghulu honorary title in Minangkabau. The title Panguluor Datuakis a hereditary title according to the Minangkabau customary Tambo based on maternal line age (matrilineal). Panghulu for the Minangkabau community has a great responsibility in managing their nephew in particular and the nagari (region) community in general. Carrying an honorary degree without being equipped with disciplines about customs, is a mental burdenon the environment. Based on that the author creates an audio visual artwork of fiction film type with the application of the concept of "representation" as a expressionof personal expression. The work manship method use sthe principle of filmmaking in general, namely the stages of pre-production (preparation process), production (manufacturing process), and post-production (packaging or preparation).
\end{abstract}

Keywords: baban gala, panghulu, datuak, matrilineal, representation.fiction.

\begin{abstract}
ABSTRAK
Baban Gala merupakan sebuah karya audio visual terkait ekspresi personal terhadap sebuah gelar kehormatan seorangpanghulu di Minangkabau. Gelar Pangulu atau Datuak adalah gelar turun temurun menurut Tambo adat Minangkabau berdasarkan garis keturunan ibu (matrilineal). Panghulu bagi masyarakat Minangkabau memiliki tanggung jawab besar dalam mengatur anak kemenakannya secara khusus dan masyarakat nagari (wilayah) secara umum. Menyandang gelar kehormatan tanpa dibekali disiplin ilmu tentang adat istiadat, adalah suatu beban mental terhadap lingkungan. Berdasarkan hal itu penulis menciptakan sebuah karya seni audio visual jenis film fiksi dengan penerapan konsep "representasi" sebagai wujud pengungkapan ekspresi personal. Metode garapan karya menggunakan prinsip pembuatan film pada umumnya, yaitu dengan tahapan pra produksi (proses persiapan), produksi (proses pembuatan), dan paska produksi (pengemasan atau penyusunan).
\end{abstract}

Kata kunci: baban gala, panghulu, datuak, matrilineal, representasi, fiksi.

\section{PENDAHULUAN}

Gelar penghulu/ panghulu (pemimpin kaum masyarakat) di Minangkabau, merupakan pusaka; dari niniak turun kamamak, dari mamak turun ka kamanakan. Artinya, gelar ini merupakan warisan turun temurun kepada laki-laki yang sudah memenuhi syarat yakni; orang baik, dapat dipercaya, baliq (berakal), serta 
berilmu pengetahuan, berdasarkan garis keturunan pihak ibu (Matrilineal). Walaupun adat masingmasing daerah berbeda-beda, Idrus Hakimy berpendapat bahwa dalam adat orang Minangkabau ada empat macam tugas pokok bagi seorang pangulu yakni;

Masyarakat

Minangkabau

sejatinya percaya terhadap peran serta tanggungjawab seorang panghulu dalam mengatur anak kemenakannya (masyarakat yang dipimpin) secara khusus dan nagari (wilayah administratif) secara umum. Panghulu tidak hanya sekadar menjadi seorang pemimpin (kaum masyarakat), melainkan juga sebagai public figure. Panghulu merupakan sosok pemimpin yang memiliki pengaruh besar terhadap anak kemenakannya

Kekuasaan tertinggi dalam suatu kaum (suku) berdasarkan Tambo Minangkabau dari dahulu diperankan penuh oleh seorang panghulu. Semenjak zaman itu panghulu yang ada di Minangkabau adalah pemimpin bagi kaumnya (Idrus Hakimy 1994:55). Tambo adalah karya sastra sejarah yang merekam kisah-kisah legenda.

Terkait peran serta kepemimpinan, bagi penulis sebagai panghulu di kaum Koto Baranam justru menjadi faktor pembatas interaksi dalam kehidupan bermasyarakat. Keterbatasan dalam bentuk daya serta minimnya ilmu pengetahuan tentang adat Minangkabau, kerap menjadikan penulis sebagai pribadi yang kaku terhadap lingkungan sosial. Hidup dalam kelompok individu yang kental, secara tidak langsung membuat penulis dituntut mampu menjalani norma-norma berkaitan dengan adat. Pergeseran zaman menimbulkan persepsi yang menjadikan ini sebagai salah satu faktor penyebab butanya disiplin ilmu yang mengkaji tentang adat tersebut. Panghulu mesti demokratis dalam membimbing anak kemenaknnya, sebagaimana yang dipaparkan Suryami bahwa:

"Penghulu menerima usul-usul dari anggota suku untuk diputuskan dan bertanggung jawab terhadap permasalahan yang terdapat dalam sukunya. Ketika salah seorang kemenakan (terutama kemenakan perempuan) yang akan menikah, penghulu mengadakan mufakat dengan seluruh anggota kaum. Penghulu mengumpulkan segala ninik mamak dan urang sumando untuk pembagian tugas masing-masing. Begitu juga saat acara duka atau kematian, penghulu pun memutuskan segala sesuatu dengan cara musyawarah bersama anggota sukunya" (Suryami, 2014: 203-215).

Berangkat dari sebuah pengalaman, hal ini menjadi inspirasi terciptanya karya seni audio visual dengan judul "Penciptaan Film Baban Gala (Representasi Ekspresi Personal sebagai Panghulu di Minangkabau)". Karya ini merupakan media informasi secara naratif dan sinematik berdasarkan realitas sosial, kemudian direpresentasikan ke dalam media audio visual jenis film. Berdasarkan pengertiannya, representasi berasal dari bahasa Inggris, yaitu representation: perbuatan mewakili, keadaan diwakili, apa yang mewakili, atau perwakilan (Depdiknas, 2008: 1167).

Film merupakan aktualisasi dari imajinasi pengkaryanya, baik dari segi teknologi yang digunakan, maupun hal-hal menyangkut tema cerita. Umumnya penggiat film menciptakan karya audio visual untuk 
kepentingan komersial, artinya dipertunjukkan di bioskop dengan harga karcis tertentu atau diputar di televisi dengan dukungan sponsor serta iklan (Sumarno, 1996: 10). Metoda penyajian film fiksi bernuansa eksperimental, justru menjadi suguhan baru dalam merangsang sensitifitas penonton terhadap visualisasi yang dihadirkan. Film tidak hanya sebagai hiburan semata, melainkan media komunikasi yang bersifat audio visual untuk menyampaikan suatu pesan kepada sekelompok orang yang berkumpul disuatu tempat tertentu (Effendy, 1986: 134).

\section{STUDI LITERATUR}

Coinage (2017), adalah film naratif yang membuka gagasan serta konsep penciptaan penulis dalam menemukan referensi karya. Film ini diunggah lewat akun youtube Aileen Krajcik, bercerita tentang seorang pengemis buta di India. Coinage diproduksi berdasarkan realita untuk kemudian direpresentasikan dengan lima jenis gaya penciptaan film; dokumenter, fiksi, realis, fantasi dan surealis. Film yang dikemas dalam durasi 20 menit ini, membentuk sebuah fragmen film dengan kejadian dan peristiwa yang berulang ulang sesuai dengan karakter gaya penggarapannya. Ilusi tokoh utama pada film Coinage hadir pada sela-sela transisi jenis gaya, hal ini memberikan komunikasi melalui visual tentang apa yang dirasakan oleh orang buta pada umumnya. Informasi yang disampaikan melalui narasi adalah bentuk dari komunikasi tokoh utama di dalam cerita ini.

Zero (2016), merupakan karya alternatif yang menjadi bahan analisa baik dari segi naratif dan sinematik.
Film ini disutradarai oleh Mihir Mahidhar dalam sebuah katalog Indian Film History yang menjadi wadah budaya perfilman di India. Zero bercerita tentang kehidupan seorang remaja penjual kopi di pinggir jalan lintas kilometer 10 kota Nanakheda, India. Film berdurasi kurang lebih 17 menit ini, berhasil menstimulus penonton merasakan hal yang sama dalam adegan panjang (Long Take) pada 10 menit awal cerita. Kehadiran Long Take dengan tempo pengambilan gambar yang pelan, memberi ruang analisa dalam setiap adegan yang dimainkan.

Visualisasi karakter dimainkan dengan gaya pemeranan naturalis untuk memberikan dampak realitas kepada penontonnya. Mihir Mahidhar menyutradarai film Zero (2016) menggunakan gaya realisme, karena kompleksnya unsur realitas yang dihadirkan. Realisme pertama kali disuarakan oleh kritikus film Prancis Andre Bazin, yang berpendapat bahwa kekuatan terbesar sinema justru terletak pada kemampuannya menghadirkan kembali realitas sebagai mana aslinya. Sehingga pada prakteknya, Bazin sangat memuja teknik pengambilan gambar sinematik yang mengandalkan direct recording process atas mise-en-scene sebuah film. Ia menganggap bahwa Long Take dan deep focus adalah salah dua cara untuk menggapai derajat realisme tertinggi.

Selain Zero, dua film klasik yang menjadi rujukan yaitu; Sitti Nurbaya (1992), diambil dari novel Kasih Tak Sampai karya Marah Rusli, serta Sengsara Membawa Nikmat, merupakan sebuah novel mahakarya Sutan Sati yang ditayangkan di TVRI pada tahun 1991. Sitti Nurbaya mengisahkan tentang pilunya cinta Sitti Nurbaya dan Samsul Bahri karena 
Samsul Bahri harus pergi ke Batavia. Faktor utama pendukung konflik film ini, karena hadirnya sosok pemeran antagonis bernama Datuk Maringgih. Ia berhasil memberikan efek dramatis kepada penonton berkat perannya.

Berbeda halnya dengan Sitti Nurbaya, film Sengsara Membawa Nikmat bercerita tentang perjalanan hidup seorang pemuda yaitu Midun disalah satu desa di Minangkabau. Midun hidup dari keluarga petani yang selalu mendapatkan fitnah dari salah satu lawan main yaitu Kacak (keponakan panghulu). Singkat cerita, Midun sebagai karakter tokoh Protagonis menjadi orang yang sukses berkat kebaikannya, sedangkan Kacak sebagai tokoh antagonis pada akhirnya harus mendekam di dalam penjara karena ulah perangainya.

Panghulu pada dasarnya adalah seseorang yang dihargai oleh banyak masyarakat, panghulu semestinya mampu memberikan contoh sikap yang baik terhadap masyarakat. Simpulan analisa penulis terhadap film ini memberikan jawaban, bahwa kaum masyarakat tanpa peran yang tegas oleh seorang panghulu akan berujung dengan tragis. Paparan ini memberikan perbandingan atau berupa evaluasi secara naratif, terhadap peran serta tanggungjawab seorang panghulu di tengah kehidupan masyarakat.

\section{METODE}

Baban Gala sebuah karya film yang menjadikan teori representasi sebagai gaya penggarapannya. Representasi merujuk kepada konstruksi segala bentuk media (terutama media massa) terhadap segala aspek realitas atau kenyataan, seperti masyarakat, objek, peristiwa, hingga identitas budaya. Representasi bisa berbentuk kata-kata atau tulisan bahkan juga dapat dilihat dalam bentuk gambar bergerak atau film.

Menurut Hall, representasi adalah sebuah produksi konsep makna dalam pikiran melalui bahasa. Ini adalah hubungan konsep dan bahasa yang menggambarkan objek, orang, maupun fisik (Hall, 1997:15). Menunjuk pada tulisan Stuart Hall, Juliastuti (2000: p.24-25) menyebutkan tiga jenis pendekatan dalam representasi antara lain:

a. PendekatanReflektif: Dalam pendekatan reflektif, sebuah makna bergantung kepada sebuah objek, orang, ide, atau peristiwa di dalam dunia nyata, dan bahasa berfungsi seperti cermin, untuk memantulkan arti sebenarnya seperti yang telahada di dunia.

\section{b. Pendekatan}

Intensional:

Pendekatan makna yang kedua dalam representasi mendebat kasus sebaliknya. Pendekatan ini mengatakan bahwa sang pembicara, penulis siapapun mengungkapkan pengertiannya yang unik ke dalam dunia melalui bahasa. Sekali lagi, ada beberapa poin untuk argumentasi ini semenjak kita semua sebagai individu, juga menggunakan bahasa untuk mengkomunikasikan hal-hal yang spesial atau unik bagi kita, dengan cara pandang kita terhadap dunia.

c. Pendekatan Konstruktivis: Ini adalah pendekatan ketiga untuk mengenali publik, karakter sosial dari bahasa.

Baban Gala merupakan film dengan format zaman modernisasi 
sesuai realita yang terjadi pada saat sekarang ini. Modernisasi sengaja menjadi pilihan rancangan garapan sebagai suatu strategi distribusi karya agar dapat diterima dan dipahami oleh masyarakat luas. Modernisasi yaitu perubahan cara pandang manusia terhadap pola kehidupan konvensional ke arah yang menjadi ciri negara Barat (pra modern), dapat diartikan modernisasi adalah transformasi sosial kehidupan masyarakat. Perubahan ini terjadi seiring dengan bergulirnya zaman, Charles Darwin (dalam Nanang Martono, 2011: 57) menyatakan bahwa perubahan sosial pada dasarnya merupakan gerakan searah, linear, progresif, dan perlahanlahan (evolutif) yang membawa masyarakat berubah dari tahapan primitif ke tahapan yang lebih maju dan membuat berbagai masyarakat memiliki bentuk dan struktur serupa.

Konsep pendekatan karya film Baban Gala, menarik Teori Peran dan sosial sebagai acuan terhadap karya ini. Peran dapat diartikan menjadi bentuk sifat atau tingkah laku yang berfungsi sebagai posisi khusus dalam hubungan tertentu. Menurut Horton dan Hunt (1993), peran (role) adalah perilaku yang diharapkan dari seseorang yang memilik isuatu status. Baban Gala yaitu tekanan tanggungjawab terhadap individu atau organisme, sebagai penyandang status sosial suatu komunitas/kelompok.

\section{HASIL DAN PEMBAHASAN}

Film Baban Gala diciptakan sebagai cara merepresentasikan realitas sosial seorang pemimpin kaum ke dalam media audio visual. Film Baban Gala adalah wujud dari cara penulis memandang realitas sosial menjalani peran sebagai pemimpin kaum, sekaligus menjadi tema dalam cerita. Tema mengerucut kepada topik pembahasan yang seiring menjadi konflik utama dalam film Baban Gala. Secara harfiah Baban Galadapat diartikan sebagai beban dari suatu identitas sosial. "Baban" jika diterjemahkan ke dalam bahasa Indonesia yaitu; beban, sedangkan "Gala" adalah gelar (status sosial). Gabungan dari dua suku kata ini bersifat majemuk, sehingga memiliki makna baru dalam pengertiannya. Defenisi makna kata baban gala yaitu; tanggung jawab yang dibebankan kepada seseorang tanpa dibekali sebuah daya. Kamus besar bahasa Indonesia (KBBI) mengartikan kata "daya" sebagai; kemampuan melakukan sesuatu/ kemampuan bertindak (https://kbbi.web.id/daya: 2019).

\subsection{Unsur-Unsur Naratif}

Film Baban Gala menurut struktur pembentuknya, terbagi dalam tiga sekuen (sequence) atau segmentasi, di mana pada setiap segmen tersebut terdapat unsur pendukung lain seperti adegan (scene) dan shot. Sekuen pada dasarnya suatu struktur terbesar yang mewakili adegan, dan biasanya dikelompokkan berdasarkan satuperiode (waktu), lokasi, atau satu rangkai anak si panjang. Namun, pada beberapa kasus film, sekuen dapat dibagi berdasarkan usia karakter utama, yakni masa balita, kanak-kanak, remaja, dewasa, serta lanjut usia.

Berdasarkan tekniknya, pengaluran dapat disusun dengan jalan progresif (alur maju) yaitu dari awal, tengah, dan akhir terjadi peristiwa atau dapat pula dengan jalan regresif (alur mundur) yaitu bertolak dari akhir cerita menuju tahap tengah atau puncak dan berakhir pada tahap 
awal (Jabrohim, 2003:111). Penulis berpatok pada teori pola linear Himawan Pratista, bisa diibaratkan dengan skema plot A-B-C-D-E dan seterusnya, dan jika diaplikasikan pada film Baban Gala maka akan menjadi seperti skema pola di bawah ini:

\section{Plot A:}

Awal cerita, hadirnya adegan prolog sebagai visual penghubung terhadap konflik dan intisari cerita. Kemudian masuk pada tahap perkenalan tokoh utama, pada film ini diperankan oleh Fajar, seorang remaja usia 18 tahun.

\section{Plot B:}

Fase ini merupakan tahapan awal terciptanya sebuah konflik terhadap tokoh utama dalam cerita. Hal ini dipicu oleh pro dan kontra dari lingkungan sosial yang melingkupi tokoh utamanya. Pemberian gelar serta menjadi orang yang berperan terhadap gelar tersebuat, merupakan faktor utama bagi tokoh dalam film Baban Gala.

\section{Plot C:}

Gelar yang diberikan kepada fajar sebagai tokoh utama dalam film Baban Gala, merupakan gelar yang membuatnya menjadi seorang pemimpin dan bertangungjawab atas anak kemenakannya.

\section{Plot D:}

Dalam visual pada plot ini, mimpi merupakan dua makna yang berbeda secara pengertiannya; (1) Suara pada galembong yang dimainkan oleh beberapa orang diibaratkan sebagai suara masyarakat yang antusias atas kepemimpinan dari tokoh utamanya (2) Sedangkan pada suara jeritan tokoh ini merupakan suatu konflik baru dalam dirinya serta lingkungan yang mengkungkungnya.

\section{Plot E:}

Tahapan akhir cerita, ego menjadi terkalahkan dan diakhiri dengan sebuah kesepakatan seorang tokoh utama dalam menjalani tugas tangung jawabnya sebagai pemimpin adat (panghulu).

Film Baban Gala dibuka dengan shot adegan prolog (istilah pembukaan pada karya sastra) yang hadir untuk memberi citraan visual pada inti cerita dalam film. Istilah prolog sendiri dalam film berupa pengawalan adegan yang saling berkaitan dengan kejadian atau peristiwa secara keseluruhan dalam cerita. Prolog berfungsi sebagai perkenalan tokoh, konflik, adegan, ruang dan waktu.

Setelah beranjak dari momen pengantar (awal) cerita, film Baban Gala masuk pada tahap tengah atau isian (konflik) cerita yang bersentuhan langsung dengan pertentangan sebab akibat. Konflik menyarankan pada pengertian sesuatu yang terjadi atau dialami oleh tokoh utama dalam cerita. Konflik dibedakan menjadi dua, yaitu konflik fisik dan konflik batin.

\section{a. Konflik Fisik}

Konflik fisik adalah konflik yang terjadi akibat dipicu oleh sesuatu hal di luar dirinya (tokoh), termasuk konflik sosial yang meliputinya. 


\section{b. KonflikBatin}

Konflik batin (internal) adalah konflik yang terjadi di dalam hati atau jiwa seorang (tokoh) cerita.

Baban Gala ditutup dengan epilog, atau tahap akhir sebuah cerita sebagai bentuk penyelesaian konflik yang dimainkan oleh tokoh cerita. Bagian ini memuat pesan dan kesan yang dideskripsikan melalui potonganpotongan adegan kepada penontonnya. Adegan akhir menjawab semua pertanyaan penonton, hal ini ditentukan oleh hubungan antar tokoh dan konflik (termasuk klimaks) yang dimunculkan.

Selain itu film tentunya memiliki elemen-elemen yang disusun hingga menjadi sebuah karya audio visual untuk dapat dipertontonkan kepada khalayaknya. Unsur naratif dan sinematik adalah elemen-elemen paling mendasar yang menjadikan film itu terlihat tampak hidup. Pratista (2008:1) menegaskan film secara umum dapat dibedakan atas dua unsur pembentukan yakni, unsur naratif dan unsur sinematik. Dua unsur tersebut saling berinteraksi dan berkesinambungan satu sama lain untuk membentuk sebuah film. Jika dari dua unsur tersebut hanya berdiri sendiri dan tidak ada kesinambungan maka tidak akan membentuk sebuah film, yang dimaksud dari unsur naratif adalah bahan (materi) yang akan diolah, sementara unsur sinematik adalah cara (gaya) untuk mengolahnya.

Unsur naratif di sini adalah yang berhubungan dengan aspek cerita atau tema film, seperti tokoh, masalah, konflik, lokasi, waktu, serta lainnya. Sebuah film yang memiliki cerita atau tema kuat bisa menjadi tidak berarti tanpa pencapaian sinematik, sementara pencapaian sinematik istimewa bisa pula tidak berarti apaapa tanpa pencapaian naratif yang mewadai. Film Baban Gala membangun unsur naratif meliputi ruang, waktu, perilaku cerita, konflik, dan tujuan.

\section{a. Ruang}

Layaknya film pada umumnya, ruang menjadi aspek yang berpengaruh terhadap unsur naratif cerita Baban Gala, ruang adalah tempat para pelaku melakukan gerak dan kreatifitas.

\section{b. Waktu}

Beberapa aspek yang berhubungan dengan naratif sebuah film yaitu waktu, di sini waktu meliputi urutan durasi dan frekuensi. Waktu merupakan pola berjalannya cerita sebuah film, maka urutan waktu tersebut menjadi pentin guntuk menentukan ritme cerita.

\section{c. Perilaku}

Perilaku cerita di sini terdiri dari karakter utama dan pendukung, karakter pendukung sering bertindak sebagai pemicu konflik atau kadang sebaliknya dapat membantu karakter utama dalam menyelesaikan masalahnya.

\section{d. Konflik}

Konflik dapat diartikan sebagai permasalahan yang dihadapi oleh tokoh utama untuk mencapai tujuannya.

\section{e. Tujuan}

Tujuan merupakan harapan yang disampaikan oleh pelaku utama, 
tujuan dapat bersifat fisik atau non fisik.

\subsection{Unsur-Unsur Sinematik}

Unsur yang kedua dalam membangun film yaitu unsur sinematik yang terbagi dalam empat elemen pokok yakni; mise-en-scene, sinematografi, suara/ audio, dan editing.

\section{a. Mise-En-Scene}

Mise-en-scene adalah sebuah pengungkapan gagasan yang dituangkan melalui kata-kata menjadi bentuk gambaran atau dengan kata lain merubah yang bersifat auditif menjadi bahan yang bersifat visual. Hima wanpratista (2008) menjelaskan Mise-en-scene adalah semua hal yang terletak di depan kamera yang akan diambil gambarnya dalam sebuah produksi film. Mise-en-scene sendiri mempunyai empat aspek utama, yaitu; setting, kostum, pencahayaan dan actor.

\section{b. Sinematografi}

Sinematografi secara umum dapat dibagi menjadi tiga aspek, yakni; kamera, framing, serta durasi gambar. Tahap sinematografi mulai berperan ketika seluruh aspek mise-en-scene dalam sebuah produksi film telah tersedia untuk diambil gambarnya. Pratista (2008) mengungkapkan dalam sebuah ilmu sinematrografi; "seorangpembuat film tidak hanya merekam setiap adegan, melainkan bagaimana mengontrol dan mengatur setiap adegan yang diambil, seperti jarak, ketinggian, sudut, lama pengambilan, dan lain-lain. Hal ini menjelaskan bahwa unsur sinematografi secara umum dapat dibagi menjadi tiga aspek, yakni kamera atau film, framing, dan durasi gambar" (HimawanPratista, 2008: 89).

\section{c. Suara}

Suaradalam film Baban Galameliputi dialog, monolog, musik, dan efeksuara. Suara menjadi pelengkap informasi terhadap visual film.

\section{d. Editing}

Dalam tahapin ishot-shot yang telah diambil dan dipilih diolah dan dirangkai hingga menjadi satu rangkaian kesatuan yang utuh. Aspek ini bersama penggerak kamera merupakan satu-satunya unsur sinematik murni yang dimiliki oleh seni film. Definisi editing pada tahap produksi adalah proses pemilihan serta penyambungan gambar-gambar yang telah diambil, sementara definisi editing setelah filmnya jadi (pasca produksi) adalah teknik-teknik yang digunakan untuk menggunakan tiap shot-nya.

Film memiliki elemen-elemen yang disusun hingga menjadi sebuah karya audio visual untuk dapat dipertontonkan kepada khalyaknya. Unsur naratif dan sinematik adalah elemen-elemen paling mendasar yang menjadikan film itu terlihat tampak hidup. Pratista (2008:1) menegaskan film secara umum dapat dibedakan atas dua unsur pembentukan yakni, unsur naratif dan unsur sinematik. Dua unsur tersebut saling berinteraksi dan berkesinambungan satu sama lain untuk membentuk sebuah film. Jika dari dua unsur tersebut hanya berdiri sendiri dan tidak ada kesinambungan maka tidak akan membentuk sebuah film, yang dimaksud dari unsur naratif adalah bahan (materi) yang akan diolah, sementara unsur sinematik 
adalah cara (gaya) untuk mengolahnya.

Film merupakan salah satu seni yang mengacu pada bentuk visual atau paparan berupa susunan komposisi dari unsur-unsur rupa. Penyusunannya dalam karya film memerlukan hukum dan asas, guna menghindari kemonotonan, untuk itu film memerlukan tekstur dalam penciptaanya. Tekstur pada karya film dapat dirasakan pada inderapenglihatan (peristiwa/ gerak aktor) dan inderapendengaran (suara/ citra bahasa). Tekstur pada film Baban Gala tercipta atas dasar imajinasi penulis dalam merespons sebuah fenomena, yang terangkum dalam struktur penciptan film pada umumnya.

\subsection{Analisis struktur naratif dan sinematik}

Analisis struktur naratif dan sinematik film Baban Gala penulis jabarkan dalam beberapa bentuk elemen:

\section{a. Framing/ Pembingkaian}

Pemilihan bingkai pada komposisi gambar merupakan hal paling mendasar dalam proses pembuatan sebuah film. Sinematografer harus mampu mengarahkan perhatian penonton terhadap cerita yang disampaikan melalui komposisi, ritme, dan perspektif (Blain, 2011: 4). Komposisi yang baik merupakan aransemen dari unsur gambar untuk membentuk suatu kesatuan yang serasi atau harmonis secara keseluruhan. Elemen terpenting yang harus diperhatikan di dalam pembingkaian komposisi gambar adalah tingkat kecerahan (lighting), warna, ukuran, bentuk, gerak, kecepatan, dan arah. Melalui manipulasi terhadap unsur-unsur pembingkaian komposisi gambar tersebut dapat digunakan untuk mengarahkan perhatian penonton serta menciptakan respons emosional terhadap penonton (Mascelli, 2010:201).
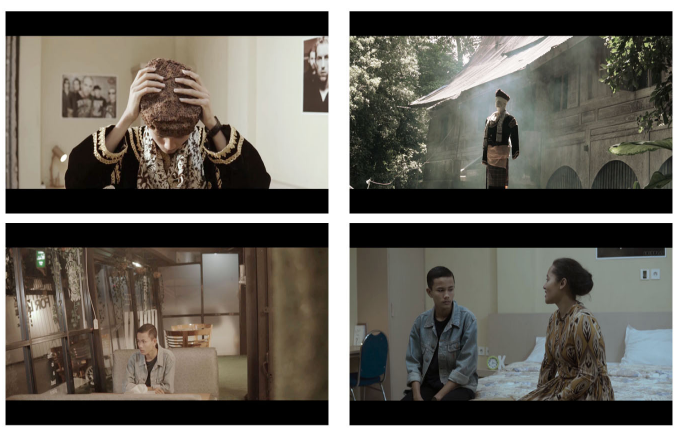

Gambar 1.

Komposisi berimbang/ simetris pada film Baban Gala (Screenshot film Baban Gala, 2019)

\section{b. Pencahaan dan Warna}

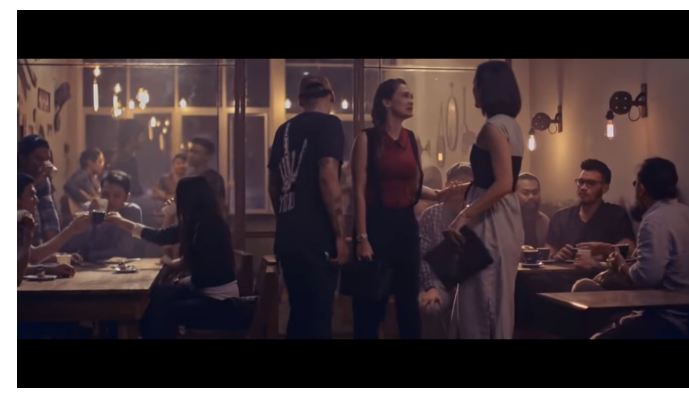

Gambar 2.

Adegan kafe pada film "Filosofi Kopi" (warna panas yang memberi efek kebersamaan) (Screenshot film Filosofi Kopi, Youtube, 2019)

Look dan Mood di dalam film Baban Gala dapat dicapai melalui pengolahan warna pada elemenelemen visual pembingkaian komposisi. Adanya asosiasi yang kuat dengan emosi, menjadikan warna pada suatu subjek memberikan energi dan menimbukan mood atau perasaan tertentu (Sugiarto, 2014: 4). 


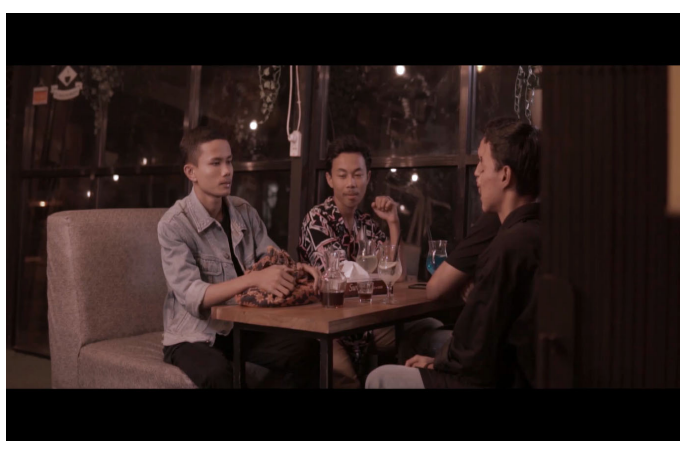

Gambar 3.

Adegankafe pada film Baban Gala (Screenshot film Baban Gala, 2019)

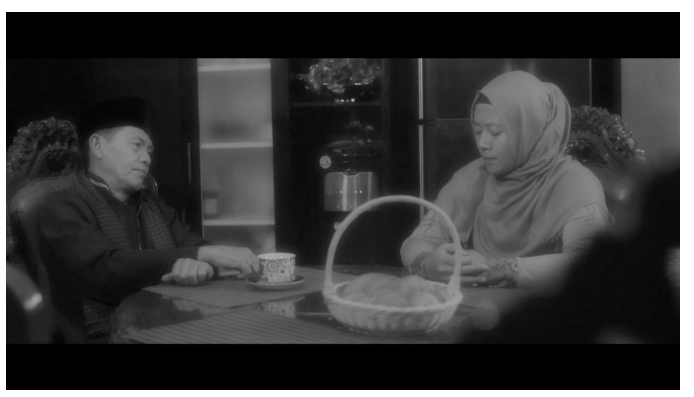

Gambar 4.

Adegansaat Angku dan Nur berdiskusidimejamakanrumah Nur (Screenshot film Baban Gala, 2019).

\section{c. Angle/ Sudut Pandang}

Sebagian besar karya film Baban Gala menggunakan kamera objektif, yaitu sudut pandang di mana penonton menyaksikan peristiwa yang dilihatnya melalui mata pengamat yang tersembunyi, seperti mata seseorang yang mencuri pandang. Namun, kamera subjektif pun turut digunakan dalam beberapa shot adegan. Sebagaimana pernyataan Himawan Pratista (2008: 111) bahwa fungsi penggunaan teknik ini adalah agar penonton mampu melihat dan merasakan sensasi sama seperti karakter dalam cerita film. Sehingga penonton ikut serta dalam peristiwa atau aksi yang ditontonnya sebagai pengalaman pribadinya. Eye Leveladalah sudut pandang kamera yang lebih banyak digunakan dalam film Baban Gala.

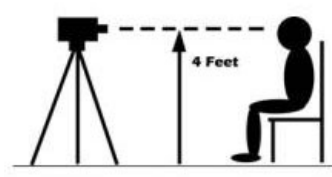

Gambar 5.

Sudutpandang Eye Level (https://studfile.net/, 2019)

\section{d. Sound/ Suara}

Suara dalam film dapat dikatakan sebagai elemen yang memberikan nilai lebih dari segi dramatik pada suatu film. Jika gambar tidak lagi sanggup menjelaskan dan tidak mampu memberikan nilai dramatik pada film tersebut maka unsur suaralah yang memiliki peran kuat dan memberikan sebuah informasi dan dramatik dalam sebuah film (Effendy, 2014:76).

Baban Gala membagi unsur suara ke dalam beberapa konsep di antaranya:

\section{a) Diegetic on Screen}

Diegetic on Screen adalah suara yang sumbernya dihadirkan oleh aksi yang dilakukan karakter, contohnya suara dialog, monolog, dan suara bendabenda dalam cerita.

\section{b) Diegetic off Screen}

Diegetic off Screen adalah suara yang sumbernya tidak terlihat di layar atau telah tersirat untuk hadir dalam aksi, contohnya suara narator, sound effect, dan ambience, tetapi memberikan informasi mengenai tempat kejadian itu berlangsung. 
Pemutaran film atau biasa disebut dengan istilah Premiere, adalah penampilan suatu karya untuk pertama kalinya dihadapan publik. Pemutaranbagiseoarangsineas film, merupakan capaian akhir dari sebuah proses kreatif dalam pembuatan karya. Menyelenggarakan acara pemutaran bagi pengkarya menjadi salah satu cara untuk menyampaikan gagasan dalam film kepada target audience. Tentunnya ini perlu dipersiapkan yang serius untuk mengurangi dampak negatif dalam proses kegiatantersebut, untuk itu pembentukan struktur keorganisasian dalam pemutaran film perlu dilaksanakan.

Film merupakan hasil kerjasama yang baik dari segenap kru. Secara garis besar, produksi suatu film dibagi ke dalam beberapa departemen dan dipimpin oleh kepala masing-masing. Suatu organisasi pelaksana produksi yang tidak disusun dengan rapi akan menghambat jalannya produksi, kerugian waktu dan keuangan.

\section{KESIMPULAN}

Penciptaan film Baban Gala adalah sebuah representasi penulis yang didasari realitas sosial dalam lingkungan masyarakat Minangkabau. Baban Gala merupakan film yang bercerita tentang peran kepemimpinan seorang panghulu dalam memimpin anak kemenakannya. Keberadaan film ini menimbulkan bermacam persepsi bermakna fisik dan ilusif sebagai wujud ekspresi penulis terhadap film Baban Gala. Fiksi merupakan alternatif gaya penyampaian film ini, karena sifatnya (fiksi) memiliki kemudahan dalam merespons informasi. Stuart Hall mengatakan bahwa merepresentasikan sesuatu berarti menampilkan sesuatu pemikiran melalui deskripsi ataupun imajinasi. Proses merepresentasikan adalah proses menentukan bentuk konkrit dari konsep ideologi yang abstrak, penulis dalam hal ini menjadikan kepemimpinan seorang panghulu sebagai objek material. Hall menyimpulkan dari teorinya bahwa representasi dikonstruksikan menjadi sebuah makna dan tanda, sehingga membentuk simbol-simbol personal dari orang yang merepresentasikan fenomena tersebut.

Berdasarkan hasil penciptaan dalam laporan karya ini, penulis mengajukan beberapa pokok saran/ rekomendasi sebagai berikut:

Pertama, perlunya melihat film sebagai seni yang menggabungkan audio dan visual secara utuh. Pada hakikatnya, film adalah sebuah sandiwara yang ingin menggambarkan realitas dunia kepada kita. Ada tokoh antagonis yang dihadirkan agar penonton tidak meniru tokoh ini, namun diimbangi dengan tokoh protagonis sebagai teladan.

Kedua, bagi praktisi dunia perfilman, Baban Gala bisa menjadi rekomendasi film yang baik memberikan edukatif, pengenalan akan peran dan kepemimpinan panghulu. Film Baban Gala mengandung banyak pesan budaya khususnya bagi masyarakat Minangkabau.

Keiga, diperlukan pemahaman prinsipprinsip dasar konsep penciptaan film yang baik. Hal ini dimaksudkan untuk memberikan nilai estetik sesuai kaidah yang berlaku dalam penciptaan karya audio visual jenis film.

Keempat, pada pembahasan film ini, maka penulis berharap adanya penelitian tentang masalah serupa sebagai bahan pembanding agar objektivitas karya ini dapat 
dipertanggungjawabkan dan diharapkan dapat saling melengkapi.

\section{DAFTAR PUSTAKA}

Hakimy, Idrus. (1994).Pokok-Pokok Pengetahuan Adat Alam Minangkabau, Bandung: Remaja Rosdakarya.

Suryami. (2014).

Konsep Kepemimpinan Dalam Tambo Minangkabau (Leadership Concept in Tambo Minangkabau). Kandai. 10 (2): 203-215.

Depdiknas. (2015). Kamus Bahasa Indonesia, Jakarta: Balai Pustaka.

Sumarno, Marselli. (1996). DasarDasar Apresiasi Film, Jakarta: PT. Grasindo.

Effendy, OnongUchjana. (1986). Dimensi Dimensi Komunikasi, Bandung: Alumni.

Hall, Stuart. (1997). The Work of Representation. Theories of Representation: Ed.
Stuart Hall. London. Sage Publication.

Martono, Nanang. (2011). Metode Penelitian Kuantitatif. Jakarta: PT Raya Grafindo Persada.

Horton, Paul B., dan Chester L. Hunt. 1993. Sosiologi, Jilid 1 Edisi Keenam,

(Alih Bahasa: Aminuddin Ram, Tita Sobari). Jakarta: Penerbit Erlangga.

Himawan, Pratista. (2008). Memahami Film. Yogyakarta: Homerian Pustaka.

\section{DAFTAR INFORMAN}

Dr. H. Arzul Jamaan. Dt. Endah Kayo Nan Kuniang, S.Kar.,M.Hum, Dosen Institut Seni Indonesia Padang Panjang, Kota Padang Panjang, Sumatera Barat. 17 November/ 22 Desember 2019.

M. Rizki Saibi. Dt. Pado Basa.,S.Sn, Mahasiswa Pascasarjana InstitutSeni Indonesia Padang Panjang. 19 Oktober 2019. 